\title{
Handling Money: Credit Use ${ }^{1}$
}

Mary N. Harrison ${ }^{2}$

Credit is one of the most important resources available to you.

- Used wisely, credit will enable you to have a good quality of life.

- Misused, it will destroy your quality of life.

Unfortunately many people do not know how to shop for and use credit wisely.

\section{Things You Need to Know about Credit}

- Credit is using someone else's money. You will have to pay for using it.

- Credit is not a right. It is a trust that must be earned. The creditor trusts you with his/her money and believes you will pay what you owe.

- You can shop for credit. Credit costs are different at different places.

- Always compare the APR (Annual Percentage Rate). The lower the APR, the cheaper the credit cost.
- If possible, pay the total bill at the end of the month. If not possible, pay as much as you can.

- Always pay more than the minimum. Never skip a payment when it is due.

- Use credit only for essentials and emergencies.

- Do not fall for schemes such as "no payment for 6 months," or other payment-delaying offers.

- Always get a list of all charges and the total of all costs associated with a purchase before buying.

- Get a copy of any contract at the time you sign the contract. Make sure all blank spaces are filled in.

- Remember a repossession may leave you still owing money on a purchase you no longer own. If a repossessed car is sold for less than you owe, you must pay the difference in the amount you owe and the price the car sold for.

- Information, good and bad, remains on your credit report for 7 years.

1. This document is FCS5235-02, one of a series of the Department of Family, Youth and Community Sciences, Florida Cooperative Extension Service, Institute of Food and Agriculture Sciences, University of Florida. Publication: May 2002. Revised: December 2005. Please visit the EDIS Web site at http://edis.ifas.ufl.edu.

2. Mary N. Harrison, professor, Department of Family, Youth and Community Sciences, Cooperative Extension Service, Institute of Food and Agricultural Sciences, University of Florida, Gainesville, 32611.

The Institute of Food and Agricultural Sciences (IFAS) is an Equal Opportunity Institution authorized to provide research, educational information and other services only to individuals and institutions that function with non-discrimination with respect to race, creed, color, religion, age, disability, sex, sexual orientation, marital status, national origin, political opinions or affiliations. U.S. Department of Agriculture, Cooperative Extension Service, University of Florida, IFAS, Florida A. \& M. University Cooperative Extension Program, and Boards of County Commissioners Cooperating. Larry Arrington, Dean 
- Bankruptcy information remains in your report for 10 years.

\section{Check Your Monthly Credit Statement}

- Keep all charge receipts. Check them against charges on your bill each month.

- If there is a billing error, call the credit card company immediately. Follow up with a letter sent to the address given on your bill. (It is not the same place that you send your payment). You must write within 60 days of receiving the bill if you want to be legally protected.

\section{Protecting Your Cards}

- Keep your credit card in a safe place so it will not be lost or stolen.

- Always sign your credit card on the backside in ink as soon as you get the card.

- Keep receipts in one safe location. Protect your credit card numbers to keep others from using them.

- Never lend your credit card to anyone.

- If your card is lost or stolen, report it immediately using toll-free telephone numbers. Follow the call with a letter sent certified mail. You should keep a separate list of all your credit cards, the card numbers and their toll-free phone numbers.

\section{Your Credit History is Important}

People who use credit have a record of their use in a file at a credit-reporting agency (Credit Bureau). This record, called a Credit Report tells who you owe, how much, and if you pay your bills on time, late, or not at all. If you apply for credit, the creditor will check your record to see if you can be trusted to pay your bills.

If you do not have a good credit report you may not be able to get credit or you may have to pay more money to get it. A poor credit report can also keep you from being able to rent an apartment, buy a house, open a bank account, or get certain jobs.
If your credit history has problems, now is the time to work to clean it up. Make a spending plan and follow it.

If your credit record is good, continue to keep it good. If you have never used credit, now is the time to establish credit and use it carefully.

\section{Remember:}

Credit can be your servant if used wisely.

It will be a tough master if it is not used carefully. 